Tatyana Yesikova [Татьяна Есикова]

ORCID: 0000-0002-3250-6490

Российский государственный педагогический

университет им. А.И. Герцена

Санкт-Перербург, Россия

\title{
Anna Kalincheva
}

ORCID: 0000-0003-3762-1065

Sofia University "St. Kliment Ohridski"

Republic of Bulgaria

\section{ТВОРЧЕСКАЯ ДЕЯТЕЛЬНОСТЬ КАК ФОРМА СОЦИАЛЬНОЙ ИНТЕГРАЦИИ ДЕТЕЙ И ПОДРОСТКОВ С ОГРАНИЧЕННЫМИ ВОЗМОЖНОСТЯМИ}

\author{
Creative activities as a form of social integration \\ of children and adolescents with disabilities
}

https://doi.org/10.34739/sn.2020.20.02

\begin{abstract}
Аннотация. В данной статье рассматривается творческая деятельность как форма социальной интеграции детей и подростков с ограниченными возможностями здоровья. Творческая деятельность рассматривается в контексте инновационной гуманной деятельности с людьми с ограниченными возможностями здоровья, в процессе которой предлагается использовать арттерапию как метод саморегуляции личности и с целью взаимодействия между участниками. В эмпирическом исследовании А. Калиничевой выявлены возможности равноправного партнерства в процессе творческой театральной деятлельности между актерами с разными способностями в гетерогенной группе. В ходе исследования применялись: метод случая (case study), метод включенного наблюдения, беседа, полуструктурированные интервью с родителями участников с ограниченными умственными возможностями и интервью с 26 актерами группы. Выявлено, что смешанная творческая группа является моделью социальной интеграции людей с ограниченными возможносятми здоровья, что становится предпосылкой дестигматизации человека с ограниченными интеллектуальными возможностями.
\end{abstract}


Ключевые слова: социальная интеграция, молодые люди с особыми возможностями здоровья, арт-терапия, творческая театральная деятельность, ограниченные умственные возможности

Abstract: This article considers creative activity as a form of social integration of children and adolescents with disabilities. Creative activity is considered in the context of innovative humane activity with people with disabilities, in the process of which it is proposed to use art therapy as a method of personal self-regulation and for the purpose of interaction between participants. In an empirical study, A. Kalinicheva identified the possibilities of equal partnership in the process of creative theatrical activity between actors with different abilities in a heterogeneous group. The research methods were: the case study method, the method of included observation, conversation, semi-structured interviews with parents of participants with intellectual disabilities and interviews with 26 actors of the group. It was revealed that a mixed creative group is a model of social integration of people with disabilities, which becomes a prerequisite for destigmatizing a person with intellectual disabilities.

Key words: social interaction, social integration, young people with special health abilities, art therapy creative theater activities, limited mental abilities

Проблема работы с детьми и подростками, имеющими ограниченные возможности здоровья (ОВ3), в современном мире является актуальной, так как в настоящее время происходит их включение в социальное пространство. Инклюзия предполагает обеспечение равных прав в получении образования, в том числе участия в творческой деятельности детей, подростков и молодых людей, с учетом их возможностей и ограничений [Zacharuk, 2017, Ювко, 2017].

Люди с ОВ3 нуждаются в индивидуальной, комплексной, специализированной коррекционной помощи, максимальной реабилитации и ранней социальной интеграции. Участие данной категории лиц в социальной жизни, а также их включение в сферы образования, культуры и искусства, несмотря на важный теоретический прогресс, недостаточны и часто минимальны [Esikova, 2018].

Важнейшим аспектом инновационной стратегии в организации специализированной помощи людям с ограниченными возможностями является образование принципиально новых форм гуманной деятельности, соответствующих современным тенденциям 
общества. Одной из таких форм инновационной педагогической деятельности с детьми и подростками с ОВЗ является творческая деятельность.

В контексте данного исследования творческая деятельность это процесс и результат получения новой оригинальной ценности для творящего субъекта. Коллективная творческая деятельность предполагает интеракцию, то есть взаимодействие участников, обеспечивающую «активную и созидательную позицию всех его участников на каждом из этапов подготовки, организации, проведения и анализа результатов» [Комарова, Ситников, Слотина, 2018, с. 60].

Примерами творческой деятельности с детьми и подростками с ограниченными возможностями здоровья являются арт-терапия, включающая изо-терапию, музыкальную и песочную терапии, а также театральную терапию в гетерогенной группе. В процессе творческой деятельности происходит развитие коммуникативных и социальных навыков с помощью искусства, снятие внутреннего напряжения, агрессии, тревожности. Все виды творческой деятельности предполагают такие этапы как сбор и анализ материала, сосредоточение усилий, инсайт, озарение в процессе нахождения нового решения творческой задачи. Творческая деятельность улучшает память, активизирует воображение, развивает речь и моторику. Достаточно эффективным считается сочетание изобразительной терапии одновременно с музыкальной терапией, или сказко-терапии и изо-терапии. Терапия искусством позволяет выявить скрытые способности обучаемых с ограниченными возможностями, избавляет их от внутренних конфликтов, развивает личность.

Арт-терапевт в игровой форме вступает в диалог с обучаемыми с ограниченными возможностями, независимо от его возраста, постепенно вызывает его доверие, узнает, что его беспокоит. Искусство в символической форме реконструирует конфликтную травмирующую ситуацию и на основе креативных способностей субъекта, позволяет посмотреть на нее с другой, позитивной стороны. Арт-терапия может быть пассивной и активной. 
При пассивной форме арт-терапии клиент «потребляет» художественные произведения созданные другими людьми, рассматривает картины, читает книги, прослушивает музыку. При активной форме арт-терапии клиент сам создает продукты творчества, рисунки, скульптуры, сочиняет сценарии для театрализованных представлений совместно с другими. Занятия творческой деятельностью могут проходить в свободной форме или быть запланированными и проводиться по определенным заранее этапам руководителя творческой группы. И в том и в другом случае необходима предварительная подготовка по сбору материала для творческой деятельности. Для творческой изобразительной деятельности нужно заранее просматривать работы известных художников и сверстников, посещать музеи и выставочные залы, организовать экскурсии в прекрасные уголки природы. Для творческой театральной деятельности предварительная работа заключается в том, что дети и подростки читают сказки и новеллы, смотрят театрализованные постановки и спектакли в лучших театрах и в творческих непрофессиональных группах.

В процессе арт-терапии, изображая переживания, субъект может «отрегулировать» их на бумаге и тем самым механически освобождается от тревожных мыслей, негативных эмоций, угнетенного самочувствия, так называемых комплексов, которые снижают наполненность самоценности. Эмоциональное напряжение, страх, гнев, угнетенность, страдания, недовольство собой во время рисования переживаются во внутренней, искусственной и безопасной для личности ситуации. В процессе рисования личность использует другой способ оценки того, что с ним произошло, переходя на образный язык вместо слова. Это с одной стороны развивает возможность "слушать себя глазами», а изображение на листе становится более осознанным, с другой стороны вылить свои переживания может и тот, кто по каким-либо причинам не может выразить это словесно. Образный язык и более безопасен, так как образ не так конкретен и понятен окружающим, а автору полностью открыт. Подсознательные конфликты и внутренние переживания легче выражаются с помощью зрительных образов. Невербальные 
образы коммуникаций могут с большей вероятностью избежать сознательной цензуры. Механизм рисования понижает внутреннее давление, угрожающее разрушением и снижением уверенности в своих силах. Рисование дает возможность работать с мыслями и чувствами, которые кажутся непреодолимыми. Иногда художественные образы - единственный инструмент, который приоткрывает и проясняет такие особенности психической деятельности и физического самочувствия, про которые не догадывается не только изотерапевт, но и сам «художник». Управляя тематикой рисования, использованием цветной гаммы можно добиться концентрации индивида на конкретных, значимых для него проблемах, их осознанности, понимания того, что происходит вокруг него с другими личностями, внутри самого себя. В результате этого может быть достигнут «катарсис» - очищение. Рисование - особый вид коммуникаций, который дает возможность рассказать о себя такое, что словами сказать он бы не осмелился, а возможно это сообщение выглядело бы грубо, вульгарно в глазах других, по соображениям рисующего компрометировало, снижало социальную ценность. Рисунок способствует лучшему самовыражению личности, усилению собственной личной ценности, обострению эмоций, сопереживанию. Рисование способствует формированию чувства внутреннего контроля и порядка, созданию системы действий и тем самым облегчает организацию деятельности и поведения.

В процессе творческой театральной деятельности создаются новые паттерны поведения, актеры креативно воплощают художественный замысел через речь, движения, жесты и мимику. Наиболее эффективно происходит социальная интеграция в гетерогенной смешанной театральной группе, в которой участнпиками являются молодые люди, здоровые и с ОВЗ, происходит социальная интеграция и социально-средовая реабилитация. Социальная интеграция способствует более активному процессу социального взаимодействия детей и подростков с ограниченными возможностями здоровья, а социально-средовая реабилитация - это комплекс мер, направленных на создание оптимальной среды их жизнедеятельности, обеспечение условий для 
восстановления социального статуса. Творческая театральная деятельность способствует получению навыков коммуникации между участниками, корректирует эмоциональное состояние личности. Взаимное чтение рисунков дает возможность понять, что и у других людей такие же или подобные проблемы, что позволяет дифференцировать закономерности их возникновения и тем самым повышает уверенность в себе, возможности преодоления трудностей.

Терапия искусством эффективно происходит с помощью творческой театральной деятельности. В процессе сочинения и репетиций спектакля участники креативного процесса делятся своими мыслями, эмоциями и желаниями с другими, реализуют свой творческий потенциал личности, превращают свой опыт в творчество и приобретают знания через опыт. Интерактивные театральные техники помогают людям, независимо от их происхождения и возможностей, узнать и принять себя и других; стимулируют личностное развитие; поощряют позитивное включение в общественную жизнь. Театральная арт-терапия, как и каждый творческий процесс, предполагает накопление опыта и знаний в воображаемой ситуации, насыщенной взаимоотношениями, конфликтами и различными поведенческими моделями, которые предоставляют участникам возможность освоить различные способы исследования своей собственной личности и личностей других через призму нереального. Это деятельность, которая позволяет актерам с инвалидностью и без инвалидности участвовать в активной ролевой ситуации для подготовки к активной жизнедеятельности, способствуя их всестороннему развитию. Благодаря включению детей-инвалидов в театральную деятельность и их сотрудничеству с детьми, развитие которых не имеет отклонений от нормы, а также общению в смешанной группе, создается безопасное пространство, позволяющее инвалидам приобретать социальные навыки.

Для изучения процесса социальной интеграции молодых людей с ОВЗ было проведено эмпирическое исследование на базе смешанной творческой группы «En Dynamei». Основными методами сбора данных являлись: включенное наблюдение, 
полуструктурированные и глубинные интервью с участниками, художественным руководителем и режиссером группы, родителями, зрителями; анализ аудиовизуальных и фотоматериалов репетиций, выступлений, гастролей, коммуникаций и взаимодействия между участниками, статей о группе «En Dynamei» в СМИ. Эмпирическое исследование является лонгитюдным, продолжалось около пяти лет и включило в себя репетиции, спектакли, гастроли и участие в международных фестивалях.

Творческая ассоциация «En Dynamei» - это коллектив молодых людей с органиченными возможностями здоровья и их сверстников без отклонений от нормы, волонтеров, родителей и друзей, регулярно взаимодействующих друг с другом и объединенных общими интересами. Созданная в Салониках (Греция) в 2008 г. по инициативе двух матерей с детьми с синдромом Дауна и аутизмом. Это сообщество обеспечивает поддержку и помощь в справедливой и достойной интеграции его членов в общество. Оно стремится предоставить людям с ограниченными возможностями оптимальную среду социализации, инкультурации и самореализации.

Анализ результатов исследования выявил, что, благодаря систематической работе и стабильным здоровым отношениям, в защищенном сообществе каждый участник группы получил развитие. Bсе члены труппы стали действительно социализированными людьми, последовательными, ответственными, обладающими развитыми чувствами, осознанием того, что они являются полноценными членами общества. Молодые люди с ОВЗ улучшили свои двигательные навыки, разработали речь, обрели уверенность в своих способностях и возможностях. Опрос родителей показал, что эти изменения проявляются в жизни вне группы, в отношениях участников «En Dynamei» со сверстниками, родственниками и друзьями. Включенное наблюдение показало, что актеры, не имеющие отклонений от нормы, и актеры с ограниченными возможностями вступают в активную коммуникацию и учатся находить подходящий способ общения и налаживания контакта с другими людьми. Исследование выявило, что в процессе театральной творческой деятельности развивалась потребность 
в общении у молодых людей с ОВЗ. Так, например, во время интенсивной репетиции перед спектаклем самая молодая участница с умственной отсталостью, Теано (16 лет), внезапно заплакала. Когда ее удалось успокоить, она объяснила: «Я плачу, потому что не хочу, чтобы это закончилось. Я хочу собираться со всеми вместе и репетировать. Боюсь, что когда мы сыграем спектакль перед зрителями, мы больше не встретимся» [Калинчева, 2018]. Такое поведение наглядно демонстрирует острую потребность людей с ограниченными возможностями в социальном взаимодействии.

На наш взгляд, дестигматизация актеров «En Dynamei» прежде всего происходит посредством целенаправленного перемещения группы стигматизированных людей С ОВ3 В пространство перформативного дискурса искусства, где правят оппозиции «странный - особенный», «неспособный - «способный», «неприемлемый - особый», «неприспосабливаемый - обучаемый», «недостаточность - разнообразие». В таком случае отличия людей с инвалидностью рассматриваются не как патология, а как неотьемлемая часть сценического образа, часть особой харизмы. В своем искусстве «En Dynamei» противостоит всему банальному и обычному, превращая «инаковость» своих членов во вдохновение для творчества, прокладывая путь для общения со зрителем, обществом и человеком. «Инаковость», «странность», «непохожесть» не скрываются, а, наоборот, подчеркиваются. Так, методами искусства совершается переключение кодов понимания инвалидности. Стигма превращается ее носителями в особенность.

Социальное взаимодействие участников творческой театральной деятельности происходит на репетициях, которые позволяют усилить сплоченность группы. Единство также усиливается с приобретением чувства принадлежности благодаря исследованию и пониманию внутреннего мира каждого участника. В дальнейшем чувство принадлежности к группе трансформируется в понимание, сопереживание и поддержку и усиливает чувство связи между участниками труппы и всеми людьми в целом. Команда достигает целей благодаря тяжелой работе, длительным репетициям и 
дисциплине с обязательным учетом времени, доступного каждому участнику.

Люди с задержкой умственного развития имеют крайне ограниченные возможности самопрезентации. Будучи носителями стигмы инвалидности, в повседневном взаимодействии они вынуждены играть преимущественно одну роль - роль «больного», «зависимого». Театр же, будучи публичным искусством, содержит в себе потенциал для преодоления стигмы. Расширение ролевого репертуара за счет освоения новой актерской роли позволяет человеку с умственной отсталостью презентовать себя иначе, прежде всего как уникальную личность. Такая личность - актер труппы «En Dynamei» Димитрис Лиррас (актер с умственной отсталостью, 26 лет). В интервью он говорит: «Актером не рождаешься, актером становишься! Я расскажу вам об актере. Актер должен иметь смелость, мужество и сердце, веру и преданность! Посвятить себя! И у нас в команде все это есть!» [Калинчева, 2018].

Перформативные высказывания в публичной сфере важны сами по себе, как и факт существования театра и статей о нем в прессе. После спектакля Человек-вентилятор, или Как одеть слона Виктор Ардитис, режиссер, преподаватель театрального факультета Аристотелевского университета в Салониках написал: «На сцене люди с умственной отсталостью и особыми навыками бок о бок, в невероятной последовательности, обмениваются и сотрудничают с людьми "в норме" - это динамическая группа "En Dynamei". Пока команда может, она должна это показать, что она доказала это. Сходным мнением делится Мария Пациду-Илиаду, советник по специальному образованию, о том. что инаковость коснулась самых сложных аспектов человеческого измерения и дала самый лучший урок, с которым не сможет конкурировать даже самая совершенная школа современности.

Современные театры, в которых играют актеры с различными функциональными нарушениями, часто позиционируют себя как социокультурные феномены, ставя перед собой цель реабилитации и инклюзии инвалидов посредством творчества. Среди других целей таких театров следует отметить поиск форм совместной работы и 
актеров-инвалидов, и актеров без отклонений от нормы, а также изменение общественного мнения о творческом и интеллектуальном потенциале инвалидов. Анализируя деятельность театра «En Dynamei», можно сделать вывод, что театральная творческая деятельность является эффективной площадкой для социальной интеграции людей с ограниченными возможностями.

\section{Literature [Литература]}

Esikova T. (2018), Inclusive education in the modern world, [in:] Jówko E., Marciniak-Paprocka K. (eds.), Social inclusion in the special education. Student teacher-environment, Wydawnictwo Naukowe UPH, Siedlce, s. 133-142.

Zacharuk T. (2017), Comparative analysis of the attitude of Polish and Ukrainian students to social exclusion, „Contemporary University Education”, nr 2, p. 44-62.

Kalinčeva A. (2018), Teatralnite tehniki kato sredstvo za podobrâvane na socialnite umeniâ prilica s uvreždaniâ, [v:] E. Rangelova (ed.), Mladi izsledovateli. Sbornik, T. 2, Universitetsko Izdatelstvo "Sv. Kl. Ohridski", Sofiâ, s. 380-405.

Komarova A., Sitnikov V., Slotina T. (2019), Sovremennye vozmožnosti primeneniâ kollektivnogo tvorčeskogo dela kak odnogoiz vidov interaktivnyh tehnologij v vysšem obrazovanii, [v:] E. Rangelova (ed.), Vzaimodejstvie na prepodavatelâ $i$ studenta $v$ usloviâta nauniversitetskogo obrazovanie: teoriâ tehnologii, upravlenie, Eks-Pres, Gabrovo, s. 58-65.

Jówko E. (2017), Model' raboty s učenikom s osobymi obrazovatel'nymi potrebnostâmi deti s sindromom Aspergera, [v:] E. Rangelova (ed.), Vzaimodejstvieconte na prepodavatelâ $i$ studenta $v$ usloviâta na universitetskogo obrazovanie: problemi i perspektivi. Sbornik s naučni dokladi. P"rva kniga, Eks-Pres, Gabrovo, s. 697-707. 